\title{
Identification and characterization of physico-chemical properties of Kithul (Caryota urens) flour for widening its applications in food industry
}

by

J A A C Wijesinghe

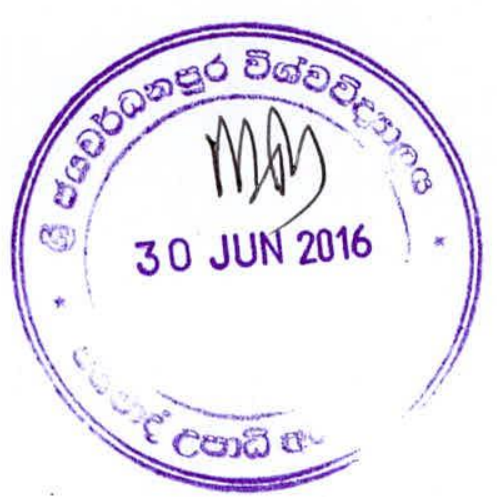

Ph.D. 
Identification and characterization of physico-chemical properties of Kithul (Caryota urens) flour for widening its applications in food industry

\author{
by \\ J A A C Wijesinghe
}

Thesis submitted to the University of Sri Jayewardenepura for the award of the Degree of Doctor of Philosophy in Food Science on 2015 . 


\section{DECLARATION}

The work described in this thesis was carried out by me at the Department of Food Science and Technology, Faculty of Applied Sciences, University of Sri Jayewardenepura under the supervision of Dr.Indira Wicramasinghe, Senior Lecturer, Department of Food Science and Technology, Faculty of Applied Sciences, University of Sri Jayewardenepura and Dr K.H Saranandha ,Head /Food Research Unit, Gannoruwa, and a report on this has not been submitted in whole or in part to any university or any other institution for another degree.

2016.06 .29

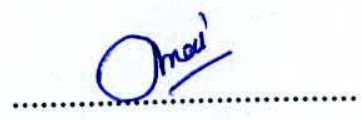

Date

J A A C Wijesinghe 
We certify that the above statement made by the candidate is true and that this thesis is suitable for submission to the University for the purpose of evaluation.

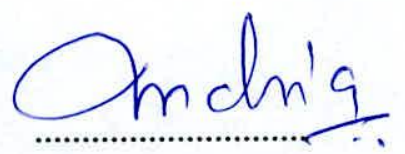

Signature

(Supervisor)

Dr Indira Wicramasinghe.

Senior Lecturer,

Department of Food Science and Technology,

Faculty of Applied Sciences,

University of Sri Jayewardenepura,

Gangodawila, Nugegoda,

Sri Lanka.

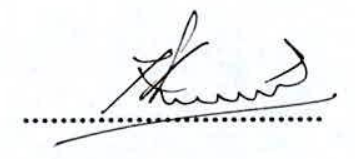

Signature

(Supervisor)

Dr K.H Saranandha

Head /Food Research Unit,

Gannoruwa,

Department of Ariculture

Kandy,

Sri Lanka. 
We certify that the candidate is submitting this thesis with all corrections, additions and amendments attended in accordance with the comments and suggestions by the examiners.

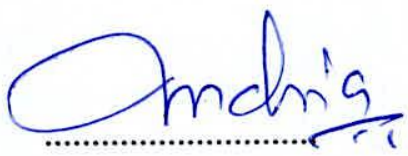

Signature

(Supervisor)

Dr Indira Wicramasinghe.

Senior Lecturer,

Department of Food Science and Technology,

Faculty of Applied Sciences,

University of Sri Jayewardenepura,

Gangodawila, Nugegoda,

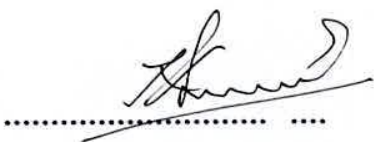

Signature

(Supervisor)

Dr K.H Saranandha

Head /Food Research Unit,

Gannoruwa,

Department of Ariculture

Kandy,

Sri Lanka. 
Dedicated to all scientists who had the courage to find the truth and speak out. 


\section{TABLE OF CONTENTS}

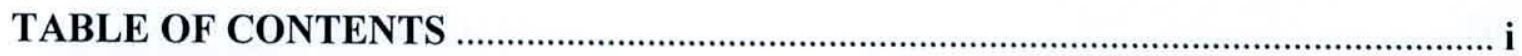

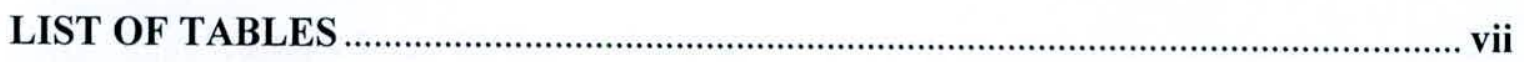

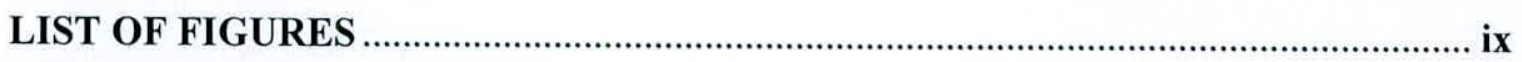

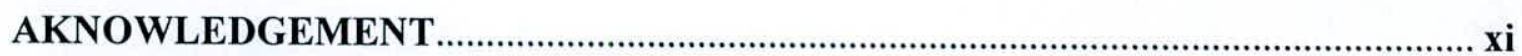

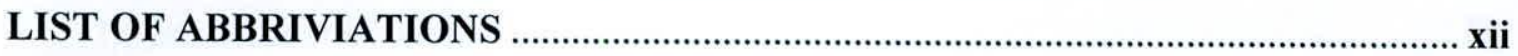

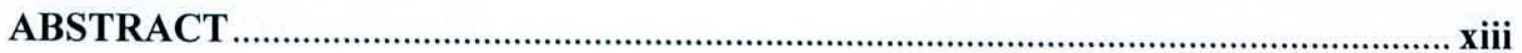

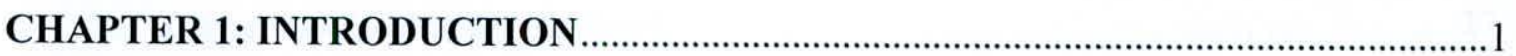

CHAPTER 2: LITERATURE REVIEW ….................................................................5

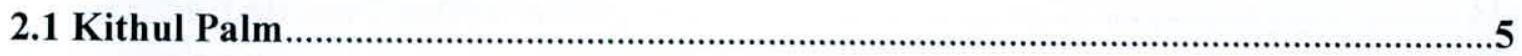

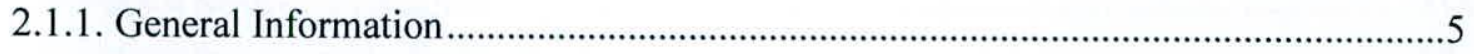

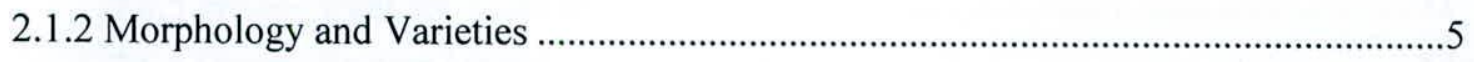

2.1.3 Origin and Distribution .......................................................................................

2.1.4 Distribution of the Kithul palm in Sri Lanka ..........................................................

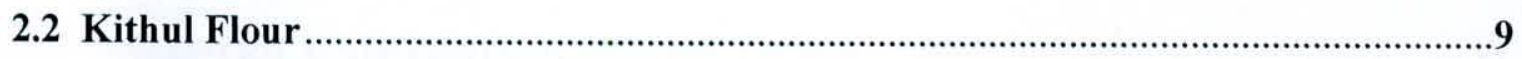

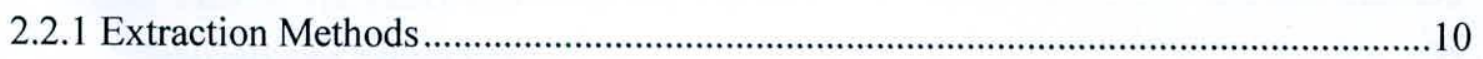

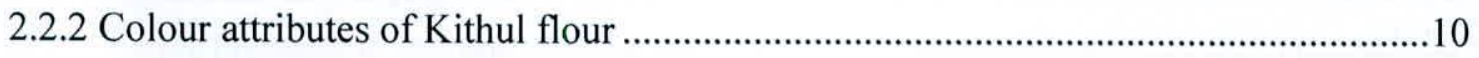

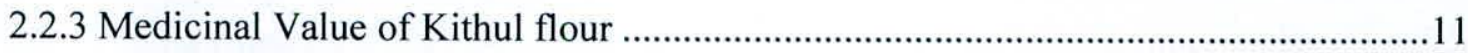

2.2.4 Current uses and potential uses of Kithul flour ...........................................................12

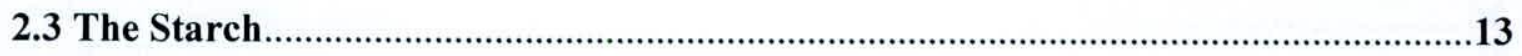

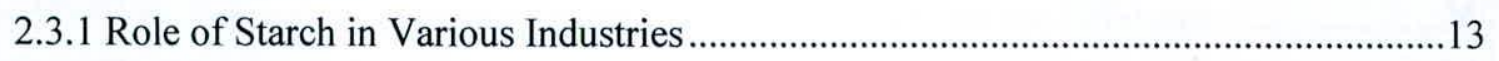

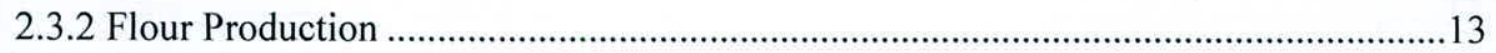

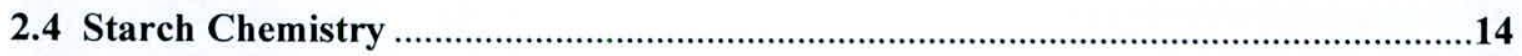

2.4.1 Role of Amylose and Amylopectin.............................................................................. 14

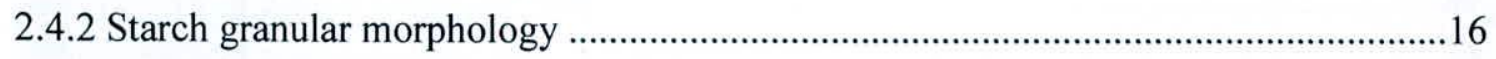

2.4.3 Physico-chemical and Functional Characteristics ...................................................... 17

2.4.3.1Determination of Colour ............................................................................... 17

2.4.3.1.1 Universal Colour Language (UCL) ................................................17

2.4.3.1.2 CIE LAB colour system measured by colourimeter ........................18 
2.4.3.2 Gelatinization Properties and Differential scanning Colourimetry (DSC) measurements

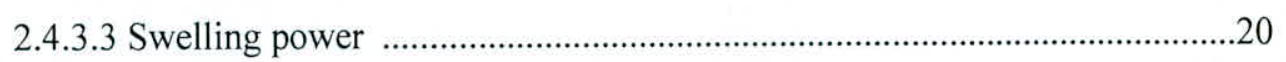

2.4.3.4 X-ray Diffraction Method ..........................................................................21

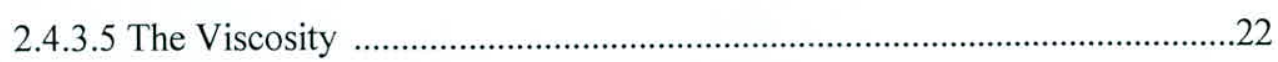

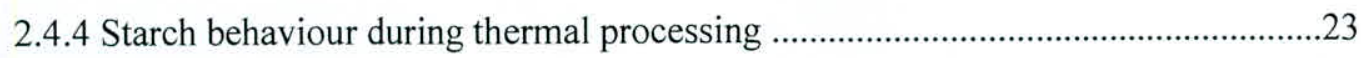

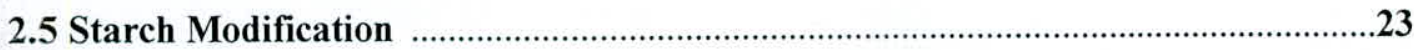

2.5.1 Different modification methods and their applications .......................................2

2.5.2 Importance of Physical modification methods ....................................................25

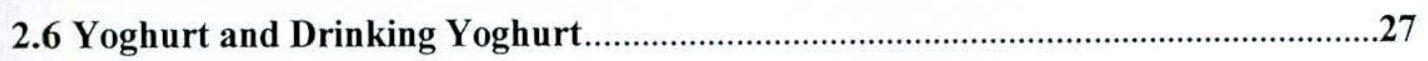

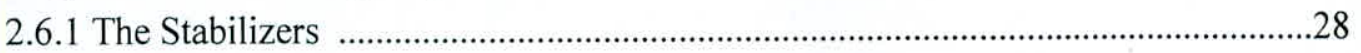

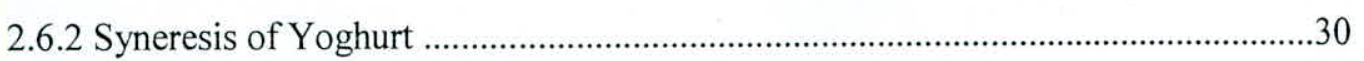

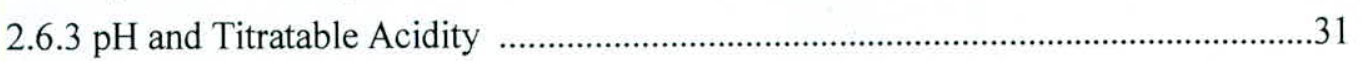

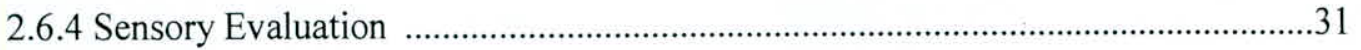

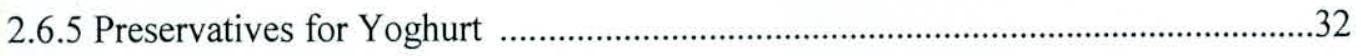

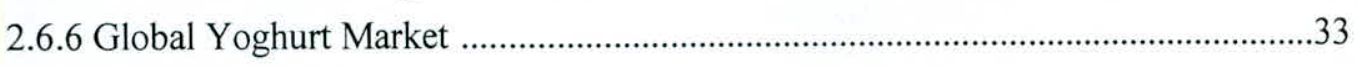

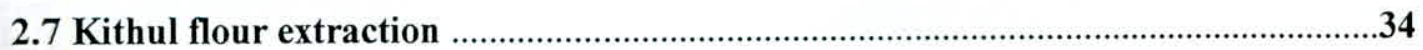

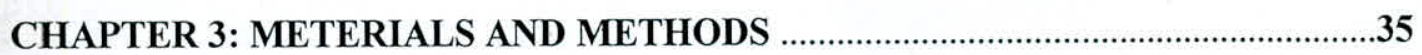

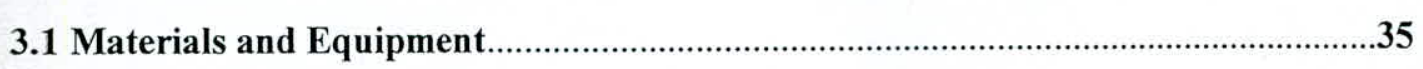

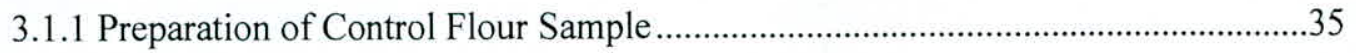

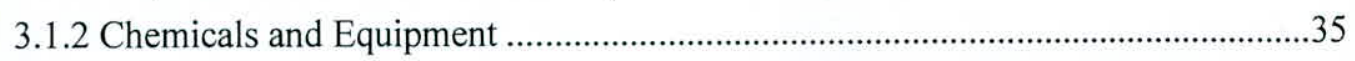

3.2 Determination of physico-chemical properties of Kithul flour from different

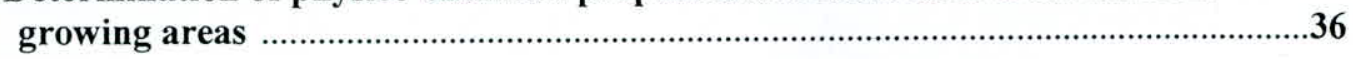

3.2.1 Selection of areas for sample collection to compare the difference ........................36

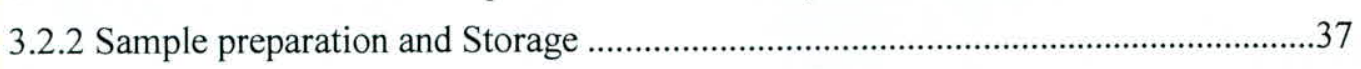

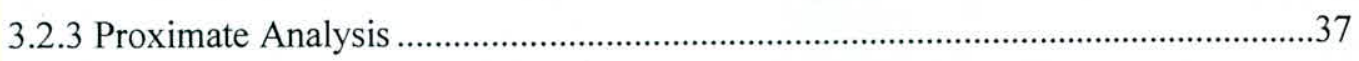

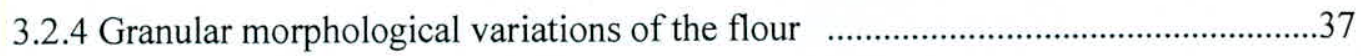

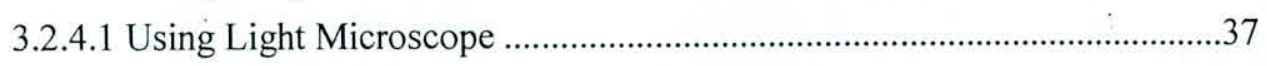

3.2.4.2 Using Scanning Electron Microscope (SEM) ............................................38

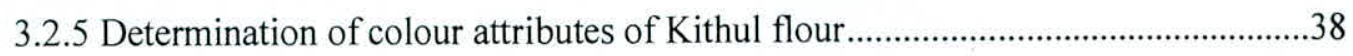

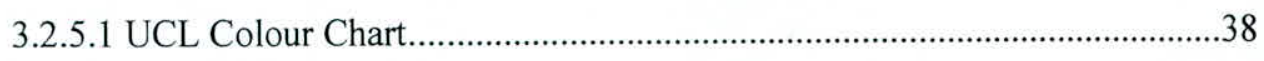

3.2.5.2 Chroma meter Minolta (CR 400) colourimeter ..........................................38 
3.2.5.3 Changes in colour attributes of Kithul flour with shelf life (By colourimeter)

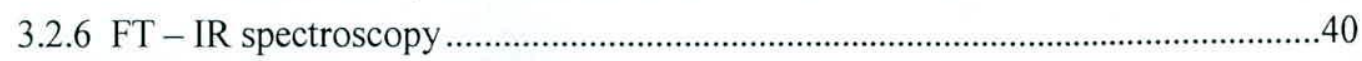

3.3 Comparison of different physical stages as tapped and non-tapped ..........................40

3.3.1. Preparation of control samples...............................................................................40

3.3.2 Sample collection from Tapped and non-tapped Kithul tree ...................................40

3.3.3 Comparison of proximate composition of Kithul flour of Tapped and non-tapped palms

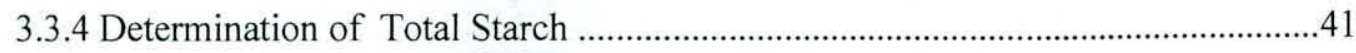

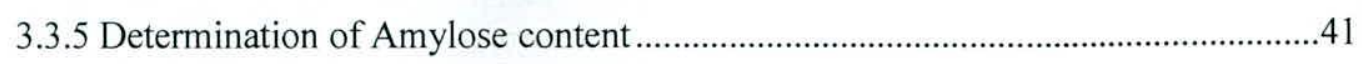

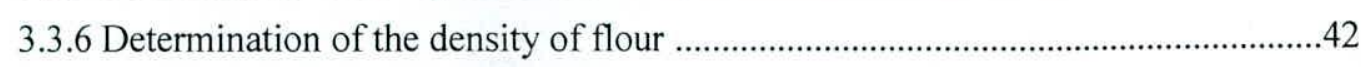

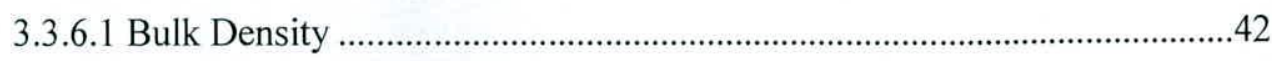

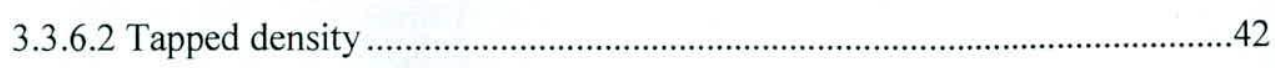

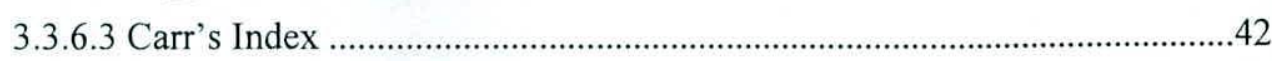

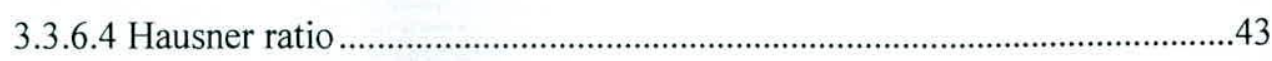

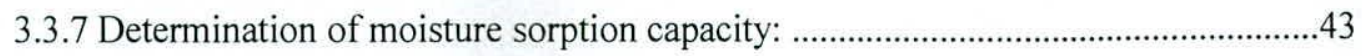

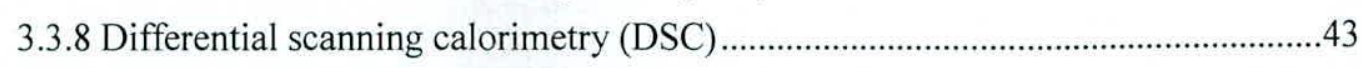

3.4 Effect of different Modification Methods on Physico-chemical properties of Kithul

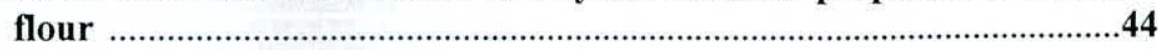

3.4.1 Pre-gelatinization modifications of Kithul flour (PG) ..........................................4

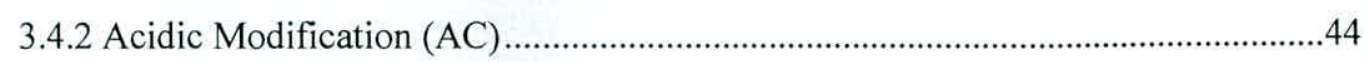

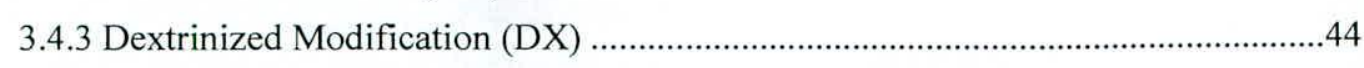

3.4.4 Comparison of Amylose content among modified Kithul flour Samples ................45

3.4.5 Comparison of gelatinization properties among modified Kithul flour Samples ....45

3.4.6 Comparison of granular morphology among modified Kithul flour Samples ..........45

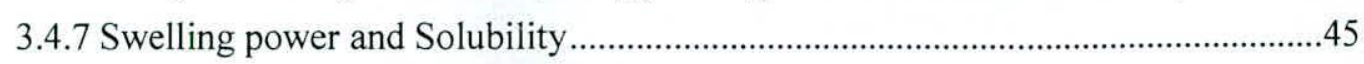

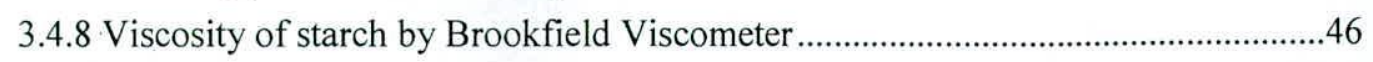

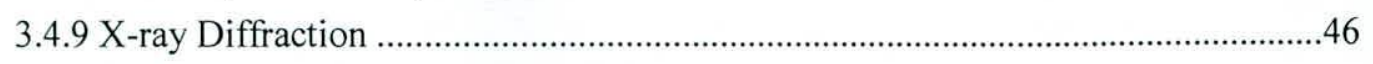

3.5 Development of drinking yoghurt with modified Kithul flour ...................................47

3.5.1 Formulation of drinking yoghurt with incorporation of Kithul flour .......................47

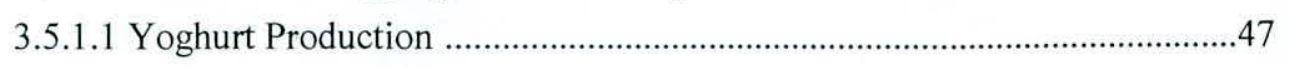

3.5.1.2 Effect of modified Kithul flour as a stabilizer ...............................................47

3.5.1.3 Pre-gelatinized Kithul flour on quality of yoghurt ......................................47

3.5.1.4 Processing method on the quality of yoghurt .............................................47 
3.5.1.5 Flour concentration on quality of yoghurt ...................................................4

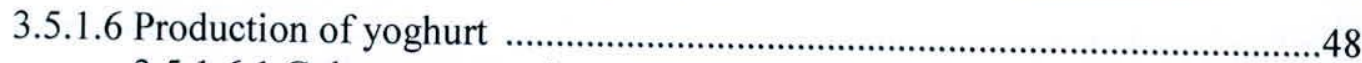

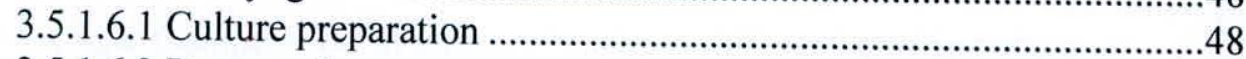

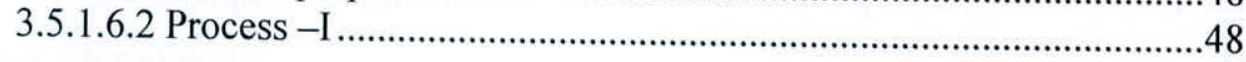

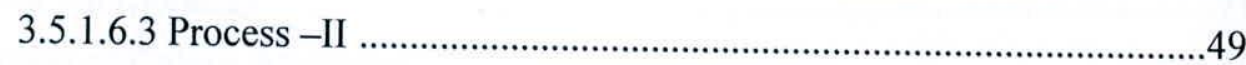

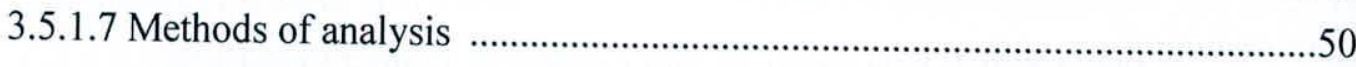

3.5.1.7.1 Determination of $\mathrm{pH}$ of the yoghurts .............................................50

3.5.1.7.2 Determination of total soluble solids (Brix ${ }^{\circ}$ Value) ........................51

3.5.1.7.3 Determination of Moisture content (\%) ..........................................51

3.5.1.7.4 Determination of total solids ( TS\%) ...........................................51

3.5.1.7.5 Sensory Evaluation ....................................................................52

3.5.2 Evaluation of selected recipe with market sample and Shelf life studies .................53

3.5.2.1 Yoghurt Production Raw Materials ..................................................................53

3.5.2.2 Proximate analysis (for sample KDY and CDY) ............................................54

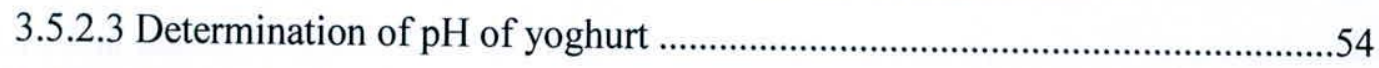

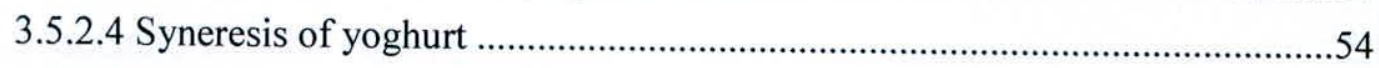

3.5.2.5 Determination of Total Titratable Acidity (TTA) .........................................55

3.5.2.6 Determination of Solid non-fat content (SNF) ..............................................55

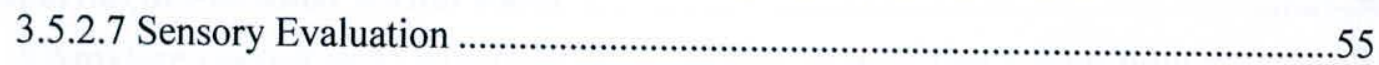

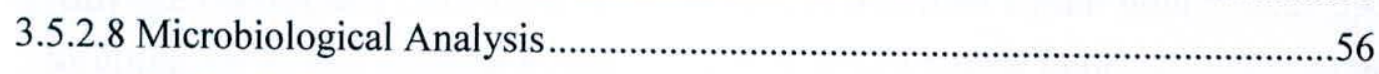

3.5.2.8.1 Total viable count ........................................................................56

3.5.2.8.2 Yeast and mold count...................................................................56

3.6 Development of Kithul Flour extraction machine: (The Design and Procedure) .....57

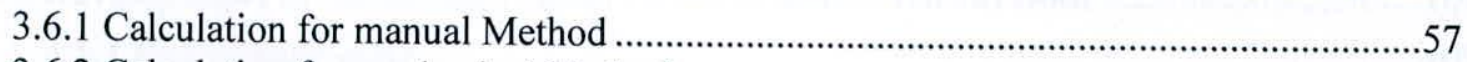

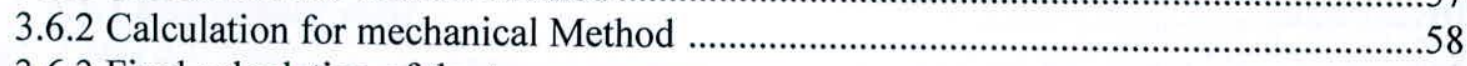

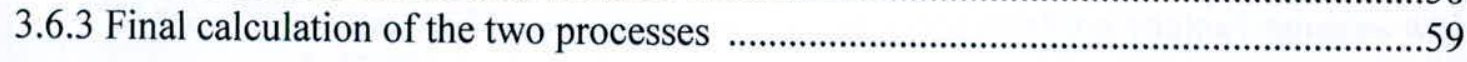

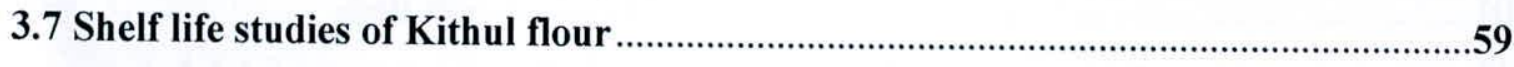

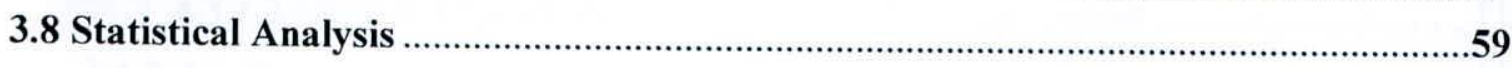

CHAPTER 04 : RESULTS AND DISCUSSION .............................................................61

4.1 Preparation of control Kithul flour extraction using traditional wet method ..........61

4.2 Comparison of Kithul flour properties from different growing areas in Sri Lanka 63 
4.2.2 The Proximate Composition of Kithul flour from different growing areas ............63

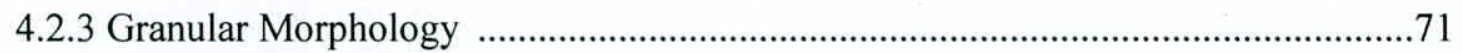

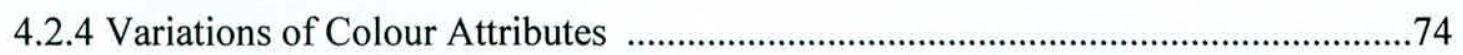

4.2.4.1 Variation of Colour in Kithul Flour by using UCL Color Chart ..................74

4.2.4.2 Comparison of Colour variations of the flour by using Chroma meter

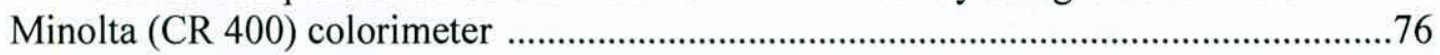

4.2.4.3 Changes in colour attributes of Kithul flour with the shelf life ..................79

4.2.5 Fourier transform infrared (FT - IR) spectroscopy …...........................................83

4.3 Comparison of flour properties obtained from tapped and non-tapped palms........87

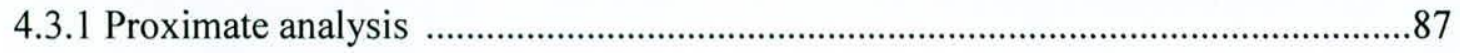

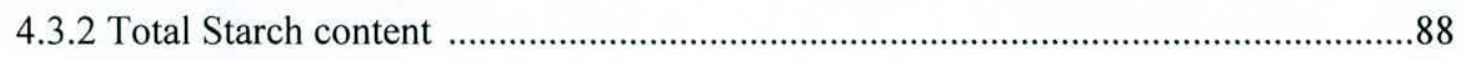

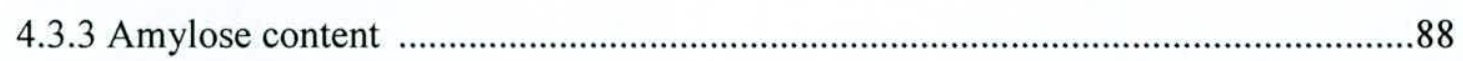

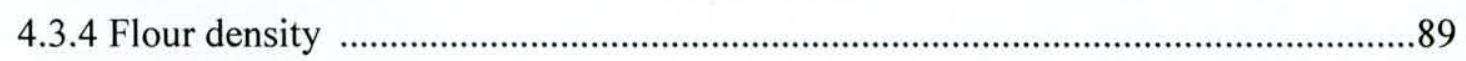

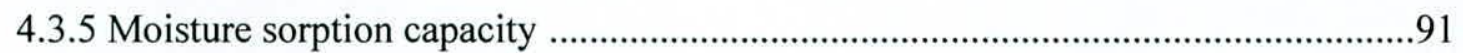

4.3.6 Gelatinizing properties ......................................................................................92

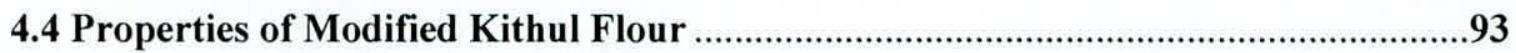

4.4.1 Amylose content and Gelatinization properties of modified Kithul flour ..............93

4.4.2 Swelling power and granular morphology of modified Kithul flour .......................98

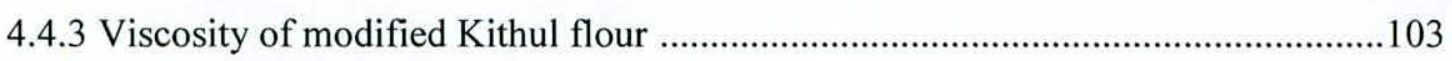

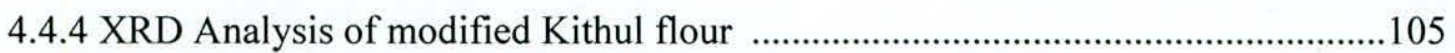

4.5 Development of Drinking yoghurt with modified Kithul flour .............................109

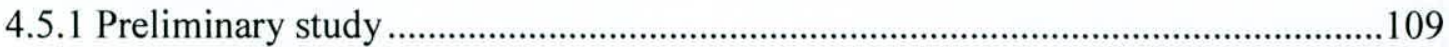

4.5.1.1 Variations of Physico-chemical properties of drinking yoghurt samples with

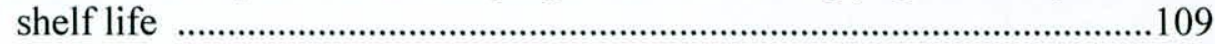

4.5.1.2 Sensory Characteristics of prepared drinking yoghurt ................................114

4.5.2 Finalizing of the new recipe for drinking yoghurt ...............................................118

4.5.3 Variations of $\mathrm{pH}$ with Shelf Life of Final Drinking yoghurt samples .....................121

4.5.4 Variations of Syneresis with shelf life of the final Drinking yoghurt samples........121

4.5.5 Apparent viscosity of the final Drinking yoghurt samples ...................................122

4.5.6 Sensory Evaluation of the final Drinking yoghurt samples ....................................123

4.5.7 Microbiological Analysis of final drinking yoghurt sample..................................125 
4.6 Development of Mechanical process for flour extraction

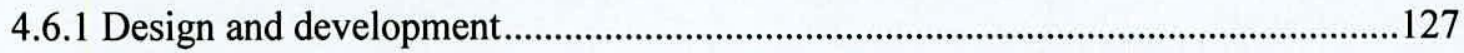

4.6.2 Comparison of the effectiveness of the two processes ............................................135

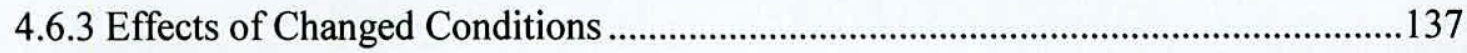

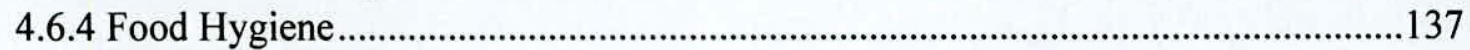

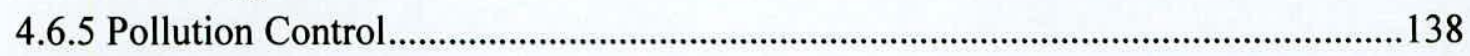

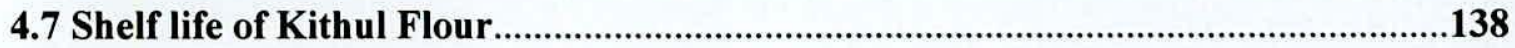

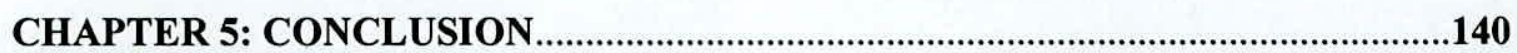

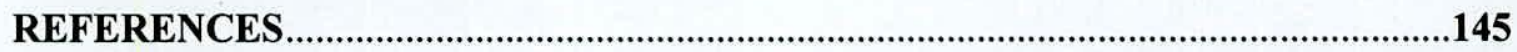

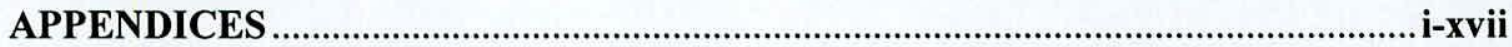




\section{LIST OF TABLES}

Table 2.1: Scientific Classification of Kithul palm ..................................................................

Table.2.2: Statistic on Kithul palms by Province ....................................................................

Table.3.1: Formulation of novel drinking yoghurt recipe with modified Kithul flour and different processes

Table 3.2: Formulation of final drinking yoghurt recipe with modified Kithul flour..............53

Table 3.3: Calculation for manual Method ..............................................................................57

Table 3.4: Calculation for Mechanical process.........................................................................58

Table.4.1: Traditional method of Kithul flour extraction ( "wet process") ............................61

Table 4.2: Variations on Chemical composition of Kithul flour collected from five different districts in Sri Lanka.

Table 4.3: Mineral content of Kithul flour collected from five different districts in Sri Lanka

Table 4.4: Variations in Granular size of Kithul flour collected from five districts in Sri Lanka.

Table 4.5: Variations on Granular shapes of Kithul flour collected from five districts in Sri Lanka.

Table 4.6: Variations in Colour attributes $\left(\mathrm{L}^{*}, \mathrm{a}^{*}, \mathrm{~b}^{*}\right)$ of Kithul flour collected from five districts in Sri Lanka.

Table 4.7: Variations in Colour attributes $\left(\mathrm{L}^{*}, \mathrm{a}^{*}, \mathrm{~b}^{*}\right)$ of Kithul flour collected from five districts in Sri Lanka vs Shelf life.

Table 4.8: Variations in Colour difference $(\Delta \mathrm{E})$ of Kithul flour collected from five districts in Sri Lanka vs Shelf life

Table 4.9: Variations on Chemical composition of Kithul flour obtained from tapped (T) and non-tapped (NT) trees

Table 4.10:Variations on Amylose, Amylopectin and total starch of Kithul flour obtain from Tapped and non-tapped trees

Table 4.11:Variations on functional properties of Kithul flour obtained from Tapped and non-tapped trees

Table 4.12:Variations on water sorption value of Kithul flour obtained from Tapped and non-tapped trees with the time.

Table 4.13:DSC transition parameters of Kithul flour obtained from Tapped and non-tapped trees with the time

Table 4.14:Amylose content and DSC transition parameters of Modified and Native flour Samples 
Table 4.15:Granular size, Swelling power and solubility results of Modified and Native Kithul flour Samples

Table 4.16:Viscosity results of Modified and Native Kithul flour Samples.

Table 4.17:Comparison of $\mathrm{pH}$ and Total Soluble Solid content of the $1^{\text {st }}$ Set of formulated Drinking Yoghurt

Table 4.18:Comparison of $\mathrm{pH}$ and Total Soluble Solid content of the $2^{\text {nd }}$ Set of formulated Drinking Yoghurt properties

Table 4.19:Comparison of $\mathrm{pH}$ and Total Soluble Solid content of the $3^{\text {rd }}$ Set of formulated Drinking Yoghurt

Table 4.20:Comparison of Moisture content and Total Solid content of the $1^{\text {st }}$ Set of formulated Drinking Yoghurt

Table 4.21:Comparison of Moisture content and Total Solid content of the $2^{\text {nd }}$ Set of formulated Drinking Yoghurt

Table 4.22:Comparison of Moisture content and Total Solid content of the $3^{\text {rd }}$ Set of formulated Drinking Yoghurt

Table 4.23:Comparison of Sensory properties of the $1^{\text {st }}$ Set of formulated Drinking Yoghurt

Table 4.24:Comparison of Sensory properties of the $2^{\text {nd }}$ Set of formulated Drinking Yoghurt

Table 4.25:Comparison of Sensory properties of the $3^{\text {rd }}$ Set of formulated Drinking Yoghurt.

Table 4.26:Variation of the Physico-chemical analysis of the two prepared Drinking yoghurt samples

Table.4.27:Variation of the Syneresis and $\mathrm{pH}$ value of Drinking yoghurt samples during the storage period

Table 4.28:Comparison of Sensory properties of the final Drinking Yoghurt formulated vs control sample and market sample

Table.4.29:Variation of the Microbiological analysis of Kithul Drinking yoghurt (KDY) sample during the storage period

Table 4.30:Comparison of the effectiveness of the two processes. 135

Table 4.31:Yeast and mould count (cfu/g) within a 3 year period of the Sample 139 


\section{LIST OF FIGURES}

Figure 2.1: Structure of amylose and amylopectin ...........................................................15

Figure 2.2: Schematic of the organization of a starch granule .............................................16

Figure 2.3: A- and B-type polymorphs of amylose ............................................................22

Figure 2.4: Global yoghurt market and consumption ..........................................................

Figure 3.1: Process of drinking yoghurt preparation ...........................................................52

Figure 4.1: Cluster Analysis for Proximate analysis of Kithul flour from five different growing areas in Sri Lanka.

Figure 4.2: Mineral content comparison of Kithul flour from five different growing areas in Sri Lanka .69

Figure 4.3: Cluster Analysis for Mineral content of Kithul flour from five different growing areas in Sri Lanka

Figure 4.4: Light micrograph (x400) of different shapes of Kithul starch granules as spherical, oval and irregular globular

Figure 4.5: Colour comparison of Kithul flour samples collected from five different districts by using UCL (Universal color language) colour codes

Figure 4.6: Cluster analysis of Colour variance of Kithul flour samples collected from five

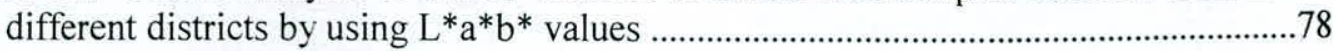

Figure 4.7: $\mathrm{L}^{*}$ value variations of Kithul Flour samples in the five districts vs Time ..........81

Figure 4.8: $a^{*}$ value variations of Kithul Flour samples in the five districts vs Time............82

Figure 4.9: $b^{*}$ value variations of Kithul Flour samples in the five districts vs Time...........82

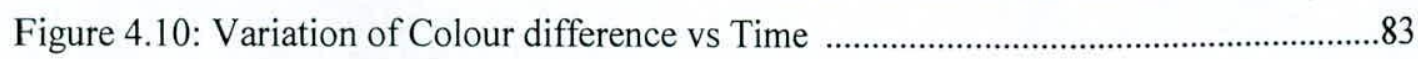

Figure 4.11: Transmission spectra obtained between 4000 and $1500 \mathrm{~cm}^{-1}$............................85

Figure 4.12: Transmission spectra obtained between 1500 and $4000 \mathrm{~cm}^{-1}$...........................86

Figure 4.13: Variations in starch components (Amylose, Total Starch and Carbohydrates) of

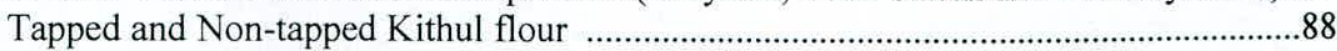

Figure 4.14: Differential Scanning colorimetry thermogram of Native and modified Kithul flour .98

Figure 4.15: SEM micrograph observations of flour treatments of Native ( RW, Left Side) and Pre-gelatinized(PG-II, Right side)

Figure 4.16: Variation of Viscosity vs Temperature of Modified and Native Kithul Flour.105

Figure 4.17: X-ray diffraction pattern of native(RW) and three modified flour treatments (AC,DX and PG-I).Array from top to bottom as AC,DX, PG-I and RW....................107

Figure 4.18: X-ray diffraction pattern of PG-II flour treatment. .........................................108 
Figure 4.19: Comparison of Sensory evaluation of Final drinking yoghurt samples. 125

Figure 4.20: Parts of the grinder 128

Figure 4.21: Drawing of the Grinder 129

Figure 4.22: Parts of the Sifter .131

Figure 4.23: Drawing of the Sifter .132

Figure.4.24: Parts of the Dryer .133

Figure 4.25: Drawing of the Dryer .134 


\section{ACKNOWLEDGEMENT}

First and foremost I wish to express my deepest gratitude to my supervisors, Dr. (Mrs.) Indira Wicramasinghe ,Senior lecturer of the Department of Food Science and Technology, Faculty of Applied sciences, University of Sri Jayewardenepura and Dr. K.H Sarananda, Head of The Department, Food Research unit, Gannoruwa for their valuable advice, patience, encouragement and guidance throughout this study and for reading the manuscript and sparing their valuable time in bringing this study to a successful completion .

I wish to express my sincere thanks to University of Sri Jayewardenepura for financial assistance under the grant of $\mathrm{ASP} / 06 / \mathrm{RE} / \mathrm{SCI} / 2012 / 04$, which have made this study a success. Special thanks to Dr. B.M.K.S Tilakaratne, Director of the Institute of Post-Harvest Technology Research and Development Centre, Anuradhapura, Dr. Meththika Vithanage, Institute of Fundamental studies, Kandy and Prof. Pathmalal Manage, Head, Department of Zoology, University of Sri Jayewardenepura for providing instrumental facility for carried out this study. Also I would like to thank all the academic and non-academic staff members of Department of Food Science and Technology, University of Sri Jayewardenepura.

It was the moral support from my friends and loving family that gave me courage to work hard to complete this report successfully; hence I express my heartfelt thanks to Miss Felicia Weerawardane, my husband Janitha Ambagaspitiya, my parents, Mr and Mrs. Wijesinghe, loving sisters Hansi, Sachini ,brother Dhammika , Arjuna, Achintha and Mr and Mrs Ambagaspitiya, finally my loving son Ghavith Kulakesha who were inspired to achieve the dream of completing the study successfully. 


\section{LIST OF ABBREVIATIONS}

ANOVA - Analysis of variance

DSC- Differential Scanning Colourimetry

FTIR - Fourier transform infrared

HMT - Heat - moisture treatment

PG - pre-gelatinized

SP - Swelling Power

AC-Acidified

DX - Dextrinized

ANN-Annealing

$T_{P}$-gelatinization temperature

Tg- glass transition temperature

$\Delta \mathrm{H}$-Gelatinization Enthalpy

$\Delta \mathrm{E}$ - Colour Difference

PDA -Potato dextrose agar

NA- Not applicable

AOAC-Official methods of Analysis of Association of Official Analytical Chemists

$\mathrm{Ca}$-Calcium

K- Potassium

Na- Sodium

Fe- Iron

Zn- Zinc

Mg- Magnesium 


\title{
Identification and characterization of physico-chemical properties of Kithul (Caryota urens) Flour for widening its applications in Food Industry
}

\author{
J A A C Wijesinghe
}

\begin{abstract}
A study was carried out to determine the possible applications of Kithul flour in food industry. The characterization of Kithul flour was based on area wise comparison and different physical stages as tapped and non-tapped which were helped to find out the suitable modification method and the use of same composite flour for bulk industrial requirements. Suitable modified flour treatment was used as a stabilizer of new drinking yoghurt formulation.
\end{abstract}

There were significant difference of Kithul flour from five different Kithul growing districts with respect to proximate and colour attributes with respect to $\mathrm{L}^{*}, \mathrm{a}^{*}, \mathrm{~b}^{*}$ and colour difference $(\Delta \mathrm{E})$. Although there were no any significant changes in granular morphology of Kithul flour which will be a positive point for using same composite flour from different growing areas in food production. The most common shape of granules in Kithul flour was oval and mean value of the starch granular length and width were $45.6 \pm 19.1$ and $26.4 \pm 9.9$ $\mu \mathrm{m}$, respectively. Shelf life of the raw Kithul flour was approximately two years and room temperature was ideal as the storing temperature. $\mathrm{L}^{*}$ (Lightness) and $+\mathrm{a}^{*}$ (redness) has improved while $+b^{*}$ (yellowness) has decreased with the time.

Physico-chemical properties among tapped and non-tapped Kithul flour were not showed any significant difference $(\mathrm{P}<0.05)$. Nevertheless in quantity wise there could be differences 
among the tapped and non-tapped Kithul trees align with the allocated time to re-accumulate after cessation of the Tapping. It will provide a perfect answer for use of tapped trees for flour production which could be helped to empower the Kithul industry by protecting both tapping industry as well as flour industry. Based on the $\mathrm{X}$ ray diffraction pattern observed for native and modified Kithul flour has clearly shown that the Kithul flour is an A- type starch.

Three modifications as pre-gelatinized (PG-I and PG-II), acid thinned (AC) and dextrinized (DX) were subjected to native Kithul flour .By taking account to all findings as differential scanning thermogram and viscosity variations this physical treatment, PG-II (prepared on $75^{\circ} \mathrm{C}$ moisture-heat treatment) is the most suitable and reliable than other treatments for food application. Specially it is appropriate use as a thickener or a stabilizer and a water retention agent for yoghurt production according to this study. Developed drinking yoghurt with modified Kithul (Caryota urens) flour (PG-II) as stabilizer was given the better results by reducing Syneresis, giving appropriate viscosity and ranking higher score for all sensory attributes except colour. Shelf life was up to 7 days with low level of preservative as 242 ppm of Potassium sorbate, at $4{ }^{\circ} \mathrm{C}$.

Finally ,mechanical process was developed (with grinder ,sifter and dryer) for flour preparation by Kithul bark in hygienic and effective manner .Further, it could be introduced as a low cost operation with better recovery yield of flour at a time effective manner which gain more profit both for manufacturer and customer. Improvement on the processing system may take time to be accomplished which leads Kithul flour production as one of the most important industries in Sri Lanka. 